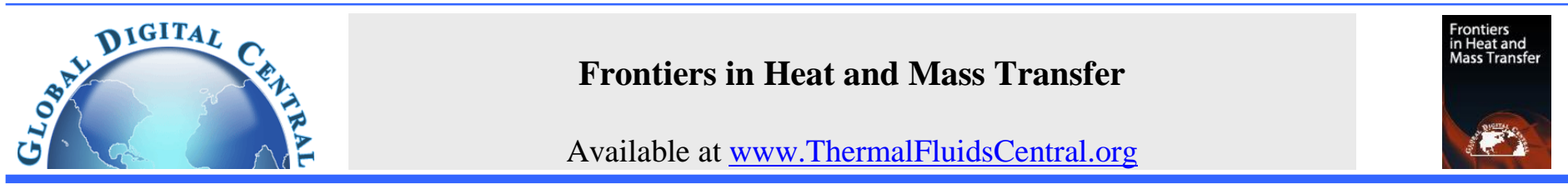

\title{
NUMERICAL ANALYSIS OF NOx PRODUCTION UNDER THE AIR STAGED COMBUSTION
}

\author{
Xiangcun Qi ${ }^{\mathrm{a}}$, Mo Yang ${ }^{\mathrm{a}, *}$, Yuwen Zhang ${ }^{\mathrm{b}}$ \\ ${ }^{a}$ School of Energy and Power Engineering, University of Shanghai for Science and Technology, Shanghai, 200093, China \\ ${ }^{b}$ Department of Mechanical \& Aerospace Engineering, University of Missouri, Columbia, MO 65211, USA
}

\begin{abstract}
The formation of thermal NO and fuel type NO emission under the air staged combustion in a tower pulverized coal fired boiler that burners are arranged in the front and the rear wall are investigated in this paper. Effects of the distribution of oxygen in the main combustion zone on $\mathrm{NO}_{\mathrm{x}}$ are then analyze qualitatively. The results show that when the SOFA ratio is $34.98 \%, \mathrm{NO}_{\mathrm{x}}$ yield is at the minimum; thermal NO is not only related to temperature, but also by the influence of oxygen distribution. When oxygen is more and the temperature is high, it is conducive to the formation of thermal NO. The formation of fuel $\mathrm{NO}$ and the amount of oxygen and $\mathrm{CO}$ have a positive correlation, and more oxygen is conducive to the formation of thermal NO. When CO is more, indicating that the reducibility is good, it will result in significant reduction of fuel NO. Based on the control of the mount of SOFA, the distribution of oxygen in the main combustion zone must be on the rational allocation; in the case of normal combustion, the input of air could not be too much through the first layer burners.
\end{abstract}

Keywords: Air staged combustion; Numerical simulation; Thermal NO; Fuel NO

\section{INTRODUCTION}

In the recent years, with the development of economy, people pay more and more attentions to energy conservation and emission reduction. The $\mathrm{NO}_{\mathrm{x}}$ is one of the main air pollutants, and reducing $\mathrm{NO}_{\mathrm{x}}$ emissions has become the main research target of many scholars worldwide. The most common methods are air staged combustion, fuel staged combustion, low oxygen combustion, flue gas recirculation, the addition of reducing agent and so on (Cen et al., 2004). Air staged combustion is the most common method to reduce the $\mathrm{NO}_{\mathrm{x}}$ for pulverized coal fired boiler.

Many scholars have done a lot of researches on air staged combustion in pulverized coal fired boiler (Kuang et al., 2011; Ma et al., 2015; Bai et al., 2014; Zhong et al., (2015) and Cheng et al., 2015). The influences of overfire air on $\mathrm{NO}_{\mathrm{x}}$ emission has been analyzed, and researches show that OFA investment made the main combustion zone be in fuel rich combustion. This is not conducive to the formation of $\mathrm{NO}_{\mathrm{x}}$, and makes the furnace exit $\mathrm{NO}_{\mathrm{x}}$ emissions reduction. Li et al. (2015) and Zhou et al. (2011) studied a 300MW coal-fired boiler and a $1000 \mathrm{MW}$ tangentially fired pulverized-coal boiler of low $\mathrm{NO}_{\mathrm{x}}$ combustion retrofit, which increases the SOFA system, making air depth classification, can reduce the production of $\mathrm{NO}_{x}$. Li et al. (2014) and Sun et al. (2013) focused on the tangentially fired boiler with low nitrogen transformation and analyzed the furnace $\mathrm{NO}_{\mathrm{x}}$ emission characteristics. Hong et al. (2012) focused on an opposed firing boiler supercritical unit and analyzed emission characteristics of $\mathrm{CO}$ and $\mathrm{NO}_{\mathrm{x}}$. All results showed that the SOFA can effectively reduce the $\mathrm{NO}_{\mathrm{x}}$ yield and the higher of air damper opening degree, the smaller $\mathrm{NO}_{\mathrm{x}}$ yield of furnace outlet.
Influences of different SOFA ratios on $\mathrm{NO}_{\mathrm{x}}$ emission in a tower pulverized coal fired boiler that burners are arranged in the front and the rear wall are investigated in this paper. Formation and influence factor of thermal NO and fuel type NO emissions are investigated under optimal operating conditions. The effect of the distribution of oxygen in the main combustion zone on $\mathrm{NO}_{\mathrm{x}}$ are analyzed. It provides a certain reference for the engineering to reduce the $\mathrm{NO}_{\mathrm{x}}$ emission by using the air staged combustion technology.

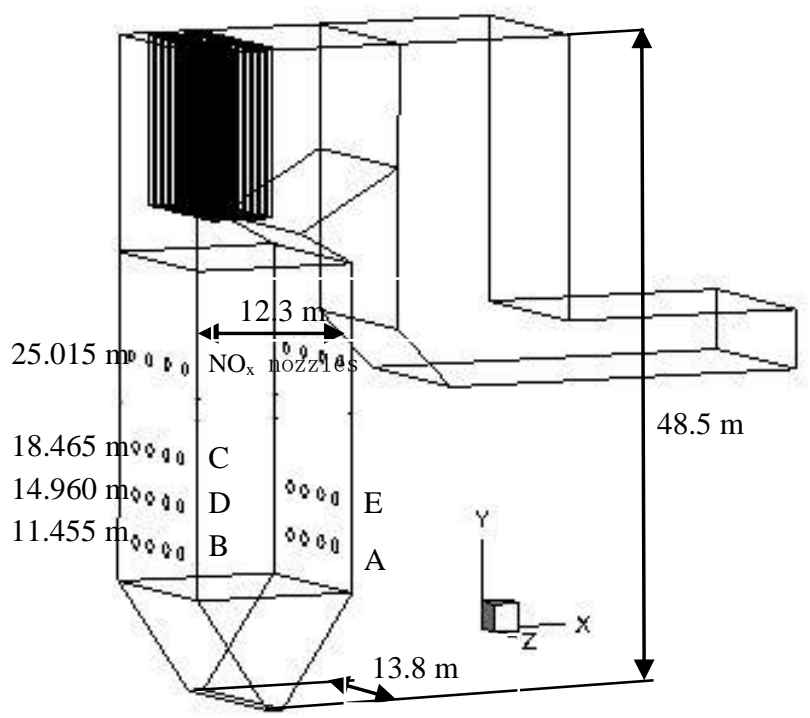

Fig. 1 Physical model and calculation model

\footnotetext{
* Corresponding author. Email: yangm@usst.edu.cn.
} 


\section{MATHEMATICAL AND PHYSICAL MODEL}

\subsection{Object of Study}

The symmetric model is usually used to reduce the computational complexity. There are a lot of papers (Yang et al., 2014; Shen et al., 2016) about nonlinear problems which prove the existence of nonlinear phenomena. In order to improve the validity of the simulation, the full scale model is used to calculate.

The object of this paper is to study a B\&WB-1025/17.5-M type single chamber, single steam drum, front and back wall convection combustion of pulverized coal boiler. This model of pulverized coal boiler is shown in Figure 1. Burners are arranged in the front and the rear wall of the boiler. The front wall is arranged with three layers of burners (from bottom to top are B, D and C), and the rear wall is arranged with two layers of burners (from bottom to top are A and E), with each layer having 4 burners; the bottom 8 burners are DRB$4 Z^{T M}$ burners, and the other 12 are AirJet ${ }^{T M}$ burners. The SOFA nozzles are arranged in the most upper burner of front and back wall, with each layer has 4 SOFA nozzles (8 only), and all SOFA nozzles are in the same elevation.

\subsection{Physical Model and Boundary Condition}

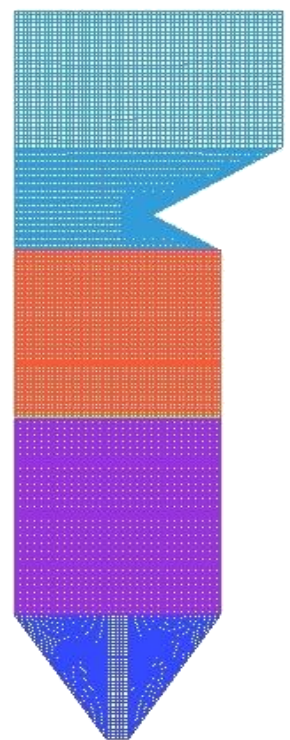

Fig. 2 Grid division in the furnace

Three-dimensional steady-state model is employed to simulate the combustion and $\mathrm{NO}_{\mathrm{x}}$ formation in pulverized coal fired boiler. Grid is structured hexahedral mesh, and specific division as shown in Figure 2. After grid size independent test, the total number of grids is about 2.26 million.

The air distribution of the two burners used in the boiler is shown in Figure 3, and pulverized coal is introduced into the furnace through the primary air. The analysis of the boiler operating conditions is $270 \mathrm{MW}$, and the excess air coefficient is 1.20 . The pulverized coal is put into the furnace through the first layer and the second layer burners. Third burners only input secondary air. SOFA is input by SOFA nozzles. This boiler coal is bituminous coal, which the element analysis and industrial analysis are shown in Table 1. All the nozzles of the burner are set to be the velocity inlet, the outlet of the furnace is set as the pressure outlet, and the wall surface of the furnace is provided with no slip boundary conditions, and the temperature of the furnace wall is $700 \mathrm{~K}$ (according to the experimental results).

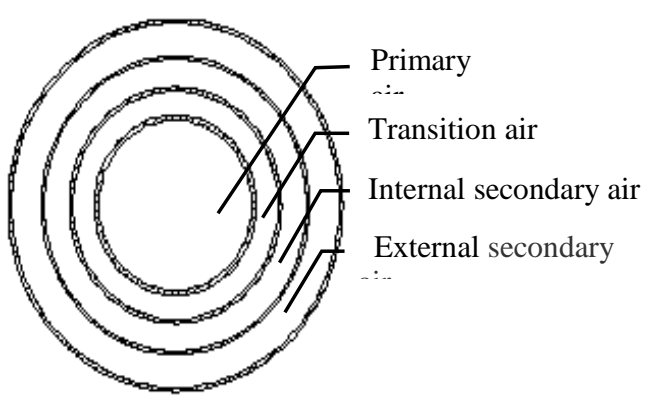

(a) DRB- $4 Z^{T M}$

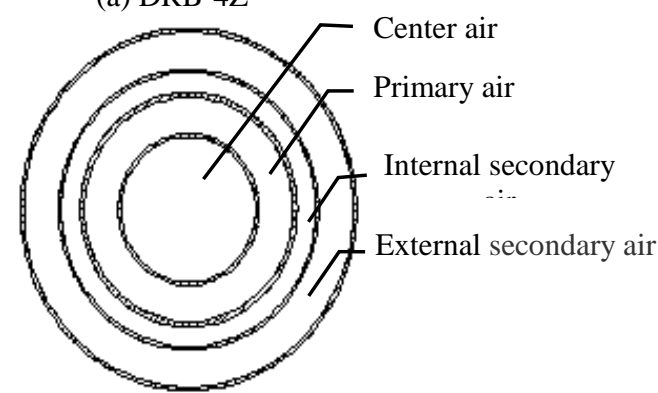

(b) AirJet $^{T M}$

Fig. 3 Air distribution of burners

Table 1 The industrial analysis and element analysis

\begin{tabular}{|c|c|c|c|c|}
\hline \multicolumn{5}{|c|}{ Industrial analysis $/ \%$} \\
\hline $\mathrm{V}_{\mathrm{ar}}$ & $\mathrm{FC}_{\mathrm{ar}}$ & $\mathrm{A}_{\mathrm{ar}}$ & $\mathrm{M}_{\mathrm{ar}}$ & $\mathrm{Q}_{\text {net }}(\mathrm{kJ} / \mathrm{kg})$ \\
\hline 26.93 & 45.39 & 16.30 & 11.38 & 23160 \\
\hline \multicolumn{5}{|c|}{ Element analysis $/ \%$} \\
\hline $\mathrm{C}_{\text {daf }}$ & $\mathrm{H}_{\text {daf }}$ & $\mathrm{O}_{\text {daf }}$ & $\mathrm{N}_{\text {daf }}$ & $\mathrm{S}_{\text {daf }}$ \\
\hline 81.33 & 5.00 & 11.42 & 1.30 & 0.95 \\
\hline
\end{tabular}

\subsection{Mathematical Model}

\subsubsection{Flow and Combustion Model}

According to the theory of combustion of pulverized coal in the furnace, gas turbulent flow model is the realization $\mathrm{k}-\varepsilon$ ( 2 eqn) model. Turbulent dispersion of coal particles uses discrete random walk model, and devolatilization model is the single-rate. The char combustion model is kinetics/diffusion-limited, and the radiation heat transfer is simulated by the $\mathrm{P} 1$ radiation model; turbulent flow diffusion flame uses the Non-Premixed combustion model (Smoot and Pratt, 1979).

The pressure based solver is used to simulate the cold and hot state of the boiler, and the patch button is used to initialize the temperature field $(2000 \mathrm{~K})$ for ignition. Firstly, the combustion in the furnace is simulated, and the generation of $\mathrm{NO}_{\mathrm{x}}$ is not considered. Finally, the post processing method is used to calculate the $\mathrm{NO}_{\mathrm{x}}$ generation.

\subsubsection{NO $_{x}$ Formation Model}

In the thermal power plant, the $\mathrm{NO}_{\mathrm{x}}$ of the pulverized coal boiler is mainly $\mathrm{NO}$ and $\mathrm{NO}_{2}$. The content of $\mathrm{NO}$ is $95 \%$ (volume concentration) of total $\mathrm{NO}_{\mathrm{x}}$. So the calculation mainly consider the generation of $\mathrm{NO}$, which can be converted into $\mathrm{NO}_{\mathrm{x}}$ through conversion relations. The generation of $\mathrm{NO}_{\mathrm{x}}$ is based on the PDF transport equation model. $\mathrm{NO}_{\mathrm{x}}$ is divided into thermal $\mathrm{NO}_{\mathrm{x}}$, fuel $\mathrm{NO}_{\mathrm{x}}$ and prompt $\mathrm{NO}_{\mathrm{x}}$. And prompt $\mathrm{NO}_{\mathrm{x}}$ is less in pulverized coal boiler, so it is neglected. 
Thermal $\mathrm{NO}_{\mathrm{x}}$ is the oxidation product of $\mathrm{N}_{2}$ in air at high temperature. And its formation process is a no branch chain reaction, mainly affected by temperature, with its formation mechanism represented by Zeldovich reaction (Hill and Smoot, 2000). Reaction 1 is the decomposition of nitrogen, due to the decomposition of the required activation energy is relatively large, so the reaction must be carried out at high temperature. The speed of the whole chain reaction is mainly determined by the slowest reaction type 1 .

$$
\begin{aligned}
& \mathrm{N}_{2}+\mathrm{O} \underset{k_{-1}}{\stackrel{k_{1}}{\rightleftharpoons}} \mathrm{N}+\mathrm{NO} \\
& \mathrm{O}_{2}+\mathrm{N} \underset{k_{-2}}{\stackrel{k_{2}}{\rightleftharpoons}} \mathrm{NO}+\mathrm{O} \\
& \mathrm{OH}+\mathrm{N} \underset{k_{-3}}{\stackrel{k_{3}}{\rightleftharpoons}} \mathrm{NO}+\mathrm{H}
\end{aligned}
$$

The fuel $\mathrm{NO}_{\mathrm{x}}$ reaction is relatively complex, using the De Soete model (Soete, 1975), and its formation is divided into two parts, the oxidation of volatile $\mathrm{N}$ and the oxidation of char $\mathrm{N}$, as shown in Figure 4. The intermediate product of volatile $\mathrm{N}$ to $\mathrm{NO}$ is $\mathrm{HCN}$ and $\mathrm{NH}_{\mathrm{i}}$. Char $\mathrm{N}$ is directly oxidized to $\mathrm{NO}_{\mathrm{x}}$. And a part of $\mathrm{NO}_{\mathrm{x}}$ can be reduced into $\mathrm{N}_{2}$.

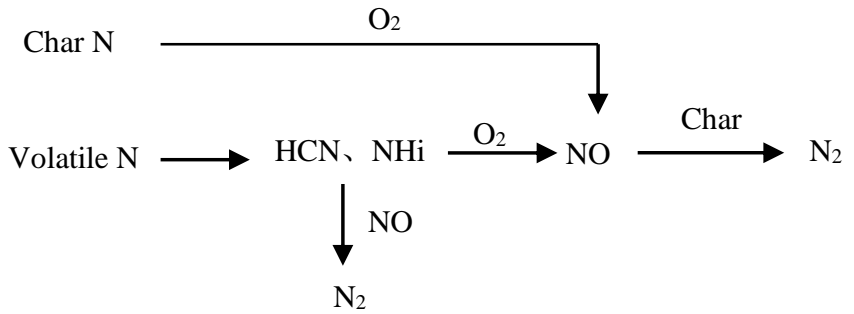

Fig. 4 Formation mechanism of fuel $\mathrm{NO}_{\mathrm{x}}$

\section{RESULTS AND DISCUSSIONS}

\subsection{Effect of SOFA on $\mathrm{NO}_{x}$}

The analysis of the boiler operating conditions is $270 \mathrm{MW}$, and the total air volume and total amount of coal remain unchanged. Conditions of six different ratios of SOFA are numerically simulated by adjusting the air ratio. Analyze $\mathrm{NO}_{\mathrm{x}}$ yield under different SOFA ratios $\left(\mathrm{NO}_{\mathrm{x}}\right.$ yield under $6 \%$ oxygen content). $\mathrm{NO}_{\mathrm{x}}$ distribution is shown in Figure 5.

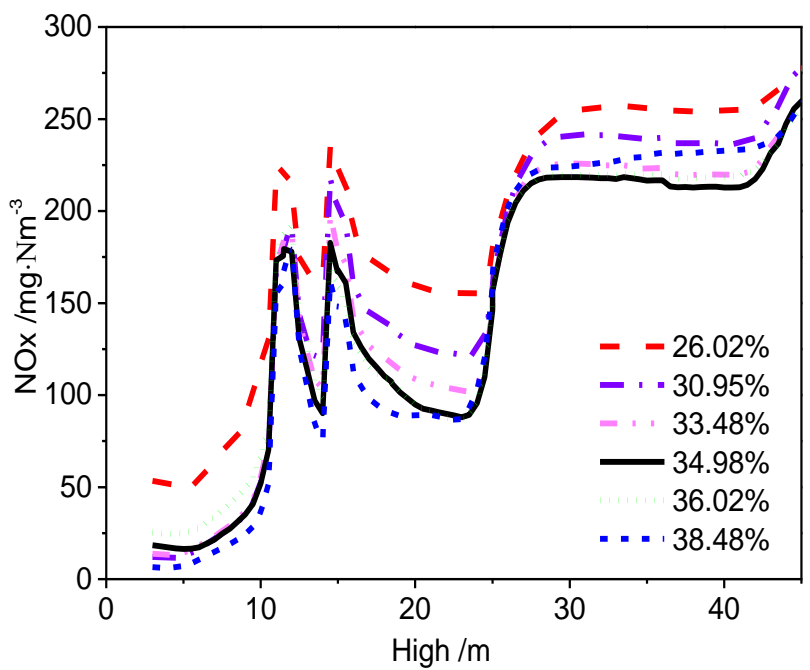

Fig. 5 The $\mathrm{NO}_{\mathrm{x}}$ distribution of different SOFA conditions
It can be seen from the figure that the air staged combustion is beneficial to reduce the $\mathrm{NO}_{\mathrm{x}}$ production in the main combustion zone. Only in the vicinity of the burner $\mathrm{NO}_{\mathrm{x}}$ production is slightly higher, the other region is in a better reducing atmosphere, is not conducive to the production of $\mathrm{NO}_{\mathrm{x}}$. And the yield of $\mathrm{NO}_{\mathrm{x}}$ and SOFA ratios have a great relationship. It is not true that the more SOFA ratio, the better air staged combustion, and the less $\mathrm{NO}_{\mathrm{x}}$ emissions. This is due to the input of SOFA through nozzles which have destroyed the reductive environment, and supply a large amount of air for coal combustion, and $\mathrm{NO}_{\mathrm{x}}$ production begin to increase. If it doesn't reasonably control the output of this area $\mathrm{NO}_{\mathrm{x}}$, even if the main fuel area $\mathrm{NO}_{\mathrm{x}}$ production is very low, still makes the furnace outlet $\mathrm{NO}_{\mathrm{x}}$ production is very large. Considering the change of the whole furnace production of $\mathrm{NO}_{\mathrm{x}}$ can be seen that with SOFA from less to more, the $\mathrm{NO}_{\mathrm{x}}$ production of furnace outlet decreased first and then increased. For the boiler in $270 \mathrm{MW}$ load, when the SOFA ratio is $34.98 \%$, the yield of $\mathrm{NO}_{\mathrm{x}}$ is minimum. So select the optimal working conditions as the research object, through the study of the distribution of $\mathrm{NO}_{\mathrm{x}}$, analysis of the generation mechanism of $\mathrm{NO}_{\mathrm{x}}$.

\subsection{Distribution of Thermal NO}

Figure 6 is the distribution of temperature and thermal NO in the longitudinal section of the furnace $(z=6.9)$. It can be clearly seen that the distribution of thermal NO is similar to temperature. In the high temperature region of the furnace, it is conducive to the generation of thermal NO. In the lower temperature zone, the thermal NO production is also less, just according with the formation mechanism of the thermal type NO.
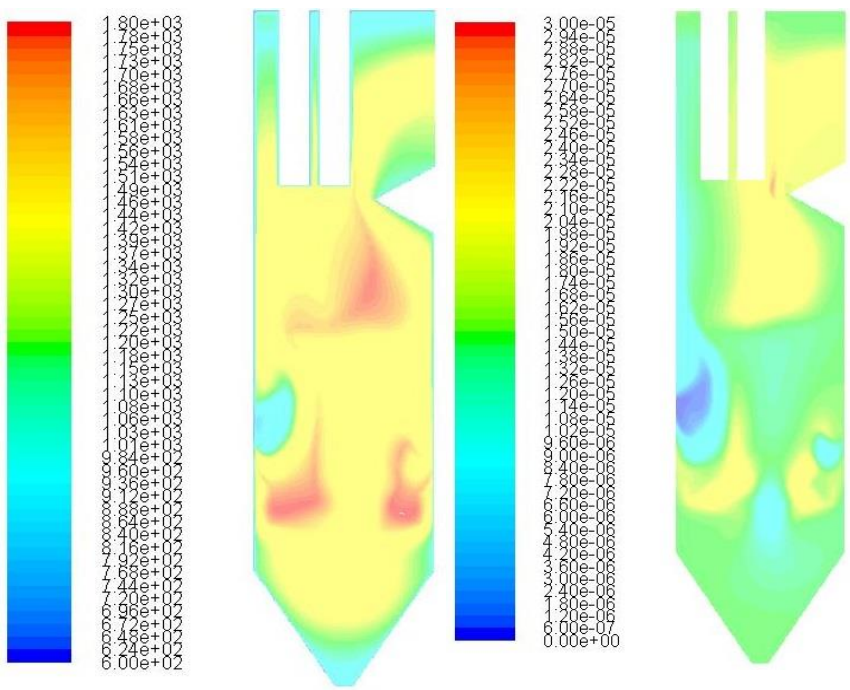

Fig. 6 The distribution of temperature $(\mathrm{K})$ and thermal NO $(\mu \mathrm{L} / \mathrm{L})$ in the longitudinal section of the furnace $(\mathrm{z}=6.9)$

And it can be seen from the figure, in addition to the high temperature region in the main combustion zone will produce a large amount of thermal NO, in the burnout zone because of SOFA input, making unburned coal combustion in the region area, the temperature increased, it is accompanied by generation of a part of thermal NO.

In order to further analyze the law of thermal NO, this paper also takes the section average value of thermal NO generation rate, temperature, oxygen and $\mathrm{CO}$ along the height of furnace, as shown in figure 7 and 8 .

From the change curve of the section average of thermal NO it can be seen that its change trend is very similar with oxygen, and from Zeldovich mechanism, it is found that the formation of thermal $\mathrm{NO}$ is not only related to temperature, but also influenced by oxygen. 
In the main combustion zone, the formation rate of thermal $\mathrm{NO}$ has been decreased two times. Because the air staged combustion to make this area as a whole is in negative oxygen combustion. The oxygen content is relatively high in the vicinity of burners, and in other areas oxygen content is very low. Therefore, the thermal NO decreased with the decrease of the oxygen content of two times. It can be seen that in the high temperature region, the formation of thermal NO is also affected by oxygen. When the oxygen is sufficient, thermal NO can be produced in a large amount; when the oxygen is insufficient, even if the temperature is appropriate, there will not be thermal NO formation.

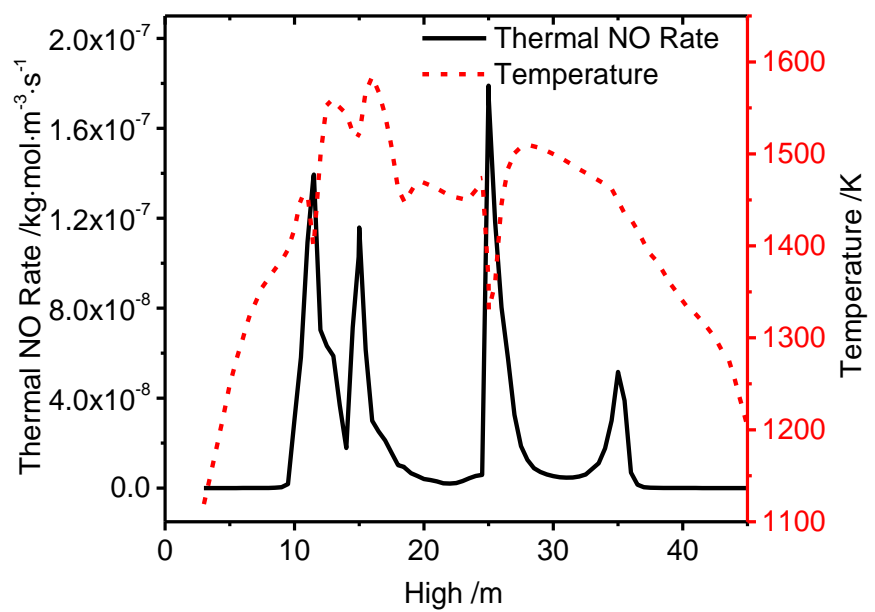

Fig. 7 The section average value of thermal NO rate, temperature

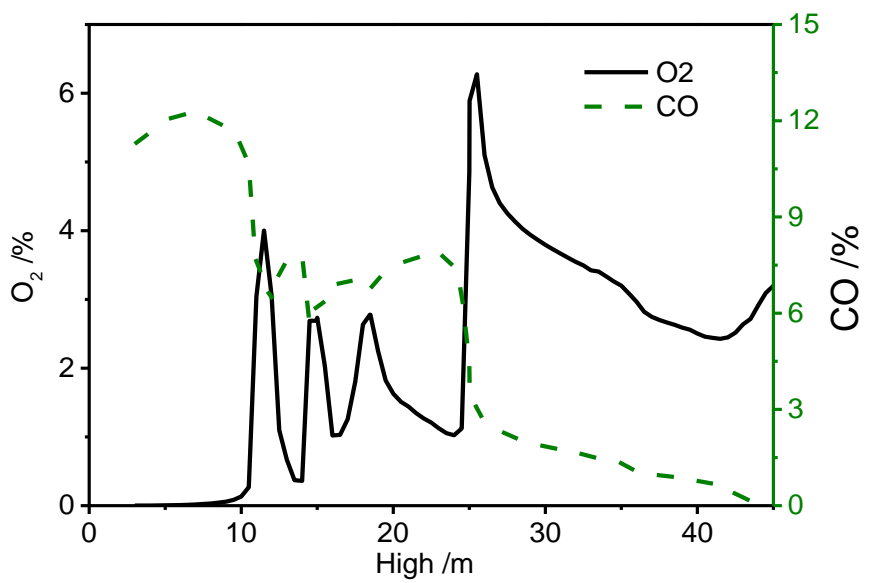

Fig. 8 The section average value of $\mathrm{O}_{2}$ and $\mathrm{CO}$

At the height of $18.5 \mathrm{~m}$, which is near the third layer burners, the oxygen content increases, but the heat type NO generation rate of the area is not increased from figure 7. From figure 8 it can be seen that the amount of $\mathrm{CO}$ in this area is very high, and form a strong reducing state, which makes some thermodynamic NO is reduced, and is not conducive to the oxidation of $\mathrm{N}$. Therefore, the region's thermal NO generation rate is very small.

At about the height of $25 \mathrm{~m}$, which is near the SOFA nozzle, because the cooling effect of SOFA, temperature decreased firstly, then with the unburned pulverized coal burning in sufficient oxygen, the temperature increased rapidly. But the change curve of the thermal NO generation rate was obviously increased at the lowest temperature. From figure 8 it can be seen that its change trend is very similar with oxygen. The three reaction of Zeldovich mechanism is used to analyze, because the temperature of the main combustion zone is relatively high, the reaction 1 is normally carried out, and the nitrogen is decomposed to generate a part of $\mathrm{N}$ atoms. But because of the relatively high amount of $\mathrm{CO}$ in the main combustion zone, the whole is in a reduced state, which is not conducive to the reaction of 2 and 3. So there is a large amount of $\mathrm{N}$ atoms to be remained in the main combustion zone. Due to the addition of SOFA, the oxygen content increased, $\mathrm{CO}$ decreased, and $\mathrm{N}$ atoms was oxidized to generate a large amount of NO by the reaction of 2 and 3 (reaction 2 and 3 don't need high temperature). The change trend of the thermal NO generation rate increases with the increase of oxygen in this region, and it seems that the relationship with temperature is not very big. In the vicinity of the Arch Nose, the thermal NO formation rate also had a small fluctuation. Because the bending angle makes the temperature of the partial area is higher.

Under the condition of the boiler, the temperature in the furnace is not very high (below $1500{ }^{\circ} \mathrm{C}$ ), which is not conducive to the formation of thermal $\mathrm{NO}_{\mathrm{x}}$. So the thermal $\mathrm{NO}_{\mathrm{x}}$ production in this boiler is relatively small, only about $12 \%$ of the total $\mathrm{NO}_{\mathrm{x}}$ yield.

\subsection{Distribution of Fuel NOx}

\subsubsection{Distribution of Volatile NO}

From the formation mechanism of fuel $\mathrm{NO}_{\mathrm{x}}$ in figure 4, fuel $\mathrm{NO}$ is divided into two parts, the oxidation of volatile $\mathrm{N}$ and the oxidation of char $\mathrm{N}$, as shown in figure 4 . In this paper, try to simulate the formation of these parts separately, so as to analyze the distribution of NO in a qualitative way. Among them, with the precipitation of volatile, volatile $\mathrm{N}$ was quickly oxidized into NO. The whole process mainly occurs near the burners in the main combustion zone, as shown in Figure 9.
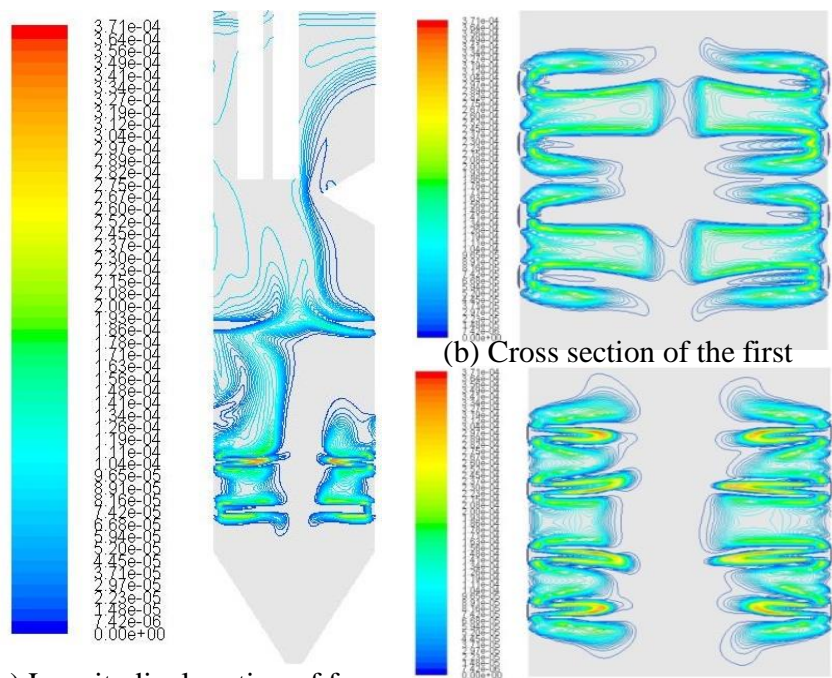

(a) Longitudinal section of furnace (c) Cross section of the second $(\mathrm{Z}=5.4375)$

Fig. 9 The distribution of volatile NO

From the volatile NO distribution of the cross sections of the first layer and the second layer of the burners can be seen, these two distributions are significantly different. The first layer is $\mathrm{DRB}-4 \mathrm{Z}^{\mathrm{TM}}$ burners. From inside to outside there are 4 channels, which are respectively primary air, transition air, internal secondary air and external secondary air. Pulverized coal with primary air enters the furnace. Volatile evaporates in the outside of the primary air, and the volatile $\mathrm{N}$ is also immediately oxidized to NO. So in the center area volatile $\mathrm{NO}$ is little and in the outer region a large amount of volatile NO will be product. The second layer is the AirJet ${ }^{\mathrm{TM}}$ burners. From inside to outside there are 4 channels, which is respectively center air, primary air, internal secondary air, and external secondary air. 
Volatile evaporates in the outside of the primary air with a large amount of volatile NO formation. So it can be seen from the figure C, volatile NO mainly generated in the region of center air and secondary air. Yield is less in the region of primary air.

\subsubsection{Distribution of Char NO}
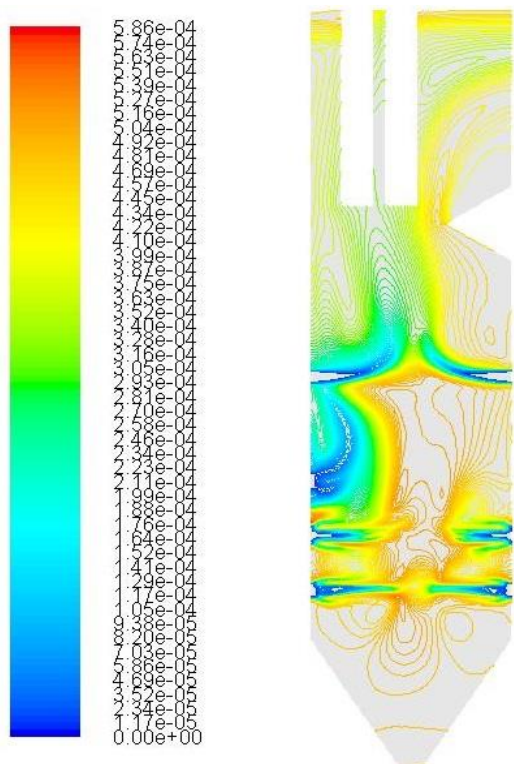

Fig. 10 The distribution of char NO $(\mathrm{Z}=5.4375)$

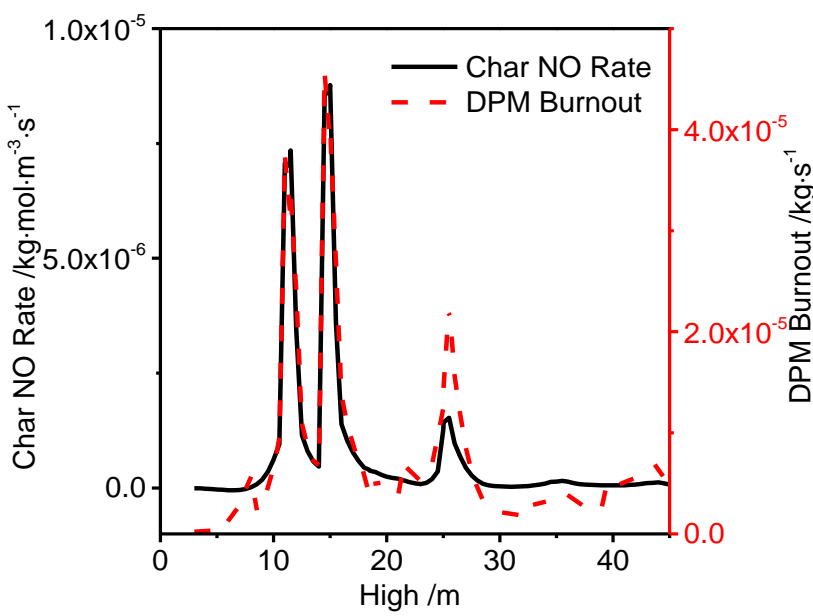

Fig. 11 The section average value of char $\mathrm{NO}$ rate and char combustion rate

Figures 10 and 11 show the distribution of char NO in the furnace $(\mathrm{Z}=5.4375 \mathrm{~m})$, and the section average value of char NO formation rate and char combustion rate along the furnace height.

From the figure it can be clearly seen that a large amount of the char NO generated in the hopper area, the main combustion zone and burnout zone. And the law of its production is almost identical with the combustion of coke. The combustion process of coke is accompanied with the production of char NO. Due to the air staged, the formation rate of $\mathrm{NO}$ was higher near the first and two layer burners in the main combustion zone. Then due to the insufficient oxygen and more $\mathrm{CO}$, reducing state is better, resulting in a reduction of the rate of char $\mathrm{NO}$, and some $\mathrm{NO}$ is reduced.

From figure 11 it can be seen that in the burnout zone because of the SOFA input, unburned char began to burn fully, it is also accompanied by the generation of a large amount of char NO. So oxygen has a great influence on the formation of char NO.

\subsubsection{Production Law of Fuel NO}

From the formation mechanism of fuel $\mathrm{NO}_{\mathrm{x}}$ in figure 4, during the actual generation of fuel $\mathrm{NO}$, the volatile $\mathrm{NO}$ and char NO are mutually influenced, especially the intermediate product $\mathrm{HCN}$ and NHi when the volatile $\mathrm{N}$ is converted to $\mathrm{NO}$, which has a great influence on the reduction of the char NO. The above methods can only be qualitative analysis of the distribution of the law, and cannot reflect the real law of fuel $\mathrm{NO}_{\mathrm{x}}$. It is still necessary to overall analysis of the various factors affecting the fuel $\mathrm{NO}_{\mathrm{x}}$.

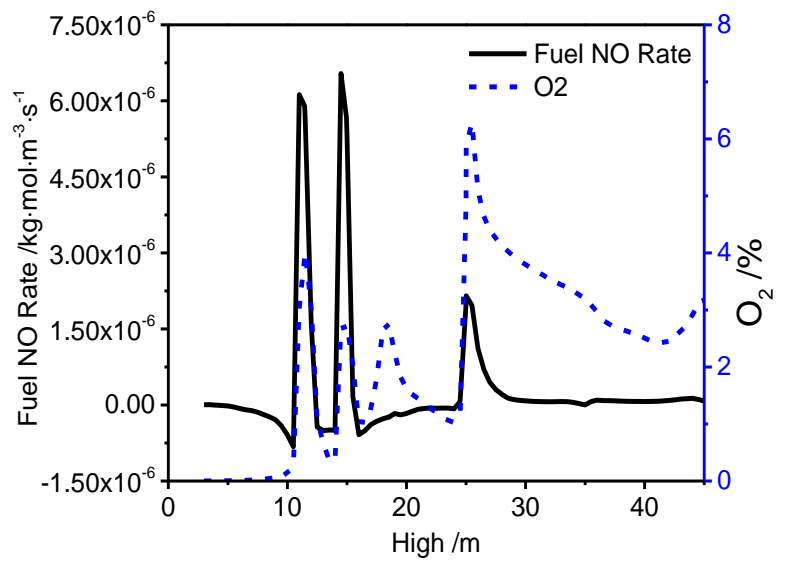

Fig. 12 The section average value of fuel $\mathrm{NO}$ rate and $\mathrm{O}_{2}$

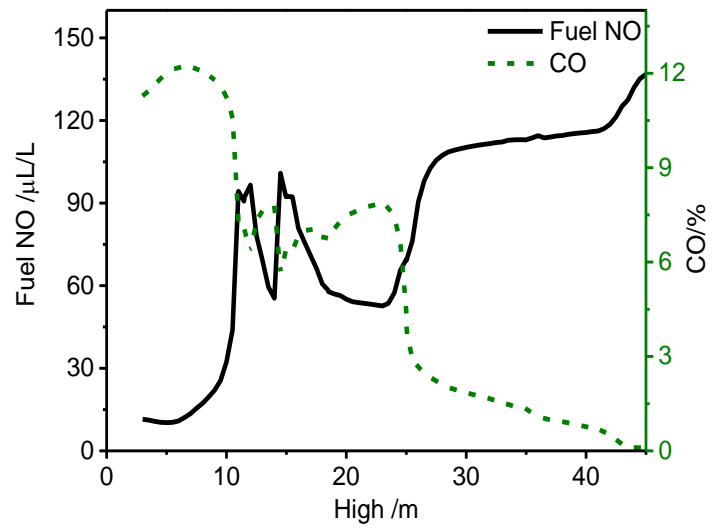

Fig. 13 The section average value of fuel $\mathrm{NO}$ and $\mathrm{CO}$

Figure 12 and 13 are the distribution of $\mathrm{O}_{2}$ and $\mathrm{CO}$ and fuel $\mathrm{NO}$ in each section of the furnace. It can be seen that the combustion is weak in hopper area duo to less oxygen, and a large amount of $\mathrm{CO}$ is generated, and fuel NO production is very small. The formation rate of the fuel NO is even negative, which shows that the NO diffused from the main combustion zone is reduced here.

Around the first layer and the second layer of the burners in the main combustion zone, due to the input of coal and adequate oxygen, the volatile is volatilized and rapid combustion, while some char is burned. So a large amount of volatile NO and char NO generated, the total fuel NO generation rate is very large. Between these two layers of burners, the amount of oxygen is consumed, which is not conducive to the formation of NO. And the amount of CO is more, so the reduction is strong, and the generated NO is reduced. The yield of fuel NO is decreased, and the production rate of fuel NO in some areas is negative. 
In the vicinity of the third layer burner, only a small amount of oxygen is put into furnace, and no coal. Although the oxygen content increased, but the amount of $\mathrm{CO}$ is still very high, is not conducive to the formation of NO. Therefore, the production of fuel NO is very small in this vicinity.

In the burnout zone, due to the inputs of SOFA, the oxygen content increased rapidly, $\mathrm{CO}$ was rapidly oxidized, so the amount of $\mathrm{CO}$ decreased rapidly. In the main combustion zone due to lack of oxygen, pulverized coal combustion is not fully, which can be fully burned in the burned zone, and accompanied by a small amount of volatile NO and a lot of char NO.

\subsection{The Effect of the Distribution of Oxygen in the Main Combustion Zone on $\mathrm{NO}_{\mathrm{x}}$}

Table 2 Air distribution parameters and $\mathrm{NO}_{\mathrm{x}}$ output of furnace outlet

\begin{tabular}{|l|l|l|l|}
\hline & Case 1 & Case 2 & Case 3 \\
\hline The ratio of primary air \% & 21.54 & 21.54 & 21.54 \\
\hline The ratio of SOFA \% & 34.98 & 34.98 & 34.98 \\
\hline The secondary air ratio of the first layer \% & 18.22 & 20.00 & 16.50 \\
\hline The secondary air ratio of the second layer\% & 18.74 & 16.96 & 20.46 \\
\hline The secondary air ratio of the third layer $/ \%$ & 6.52 & 6.52 & 6.52 \\
\hline $\mathrm{NO}_{\mathrm{x}}$ output of furnace outlet $/ \mathrm{mg} \cdot \mathrm{Nm}^{-3}$ & 215.23 & 231.56 & 217.78 \\
\hline
\end{tabular}

Keep the total air volume, total amount of coal and primary air are the same. When the SOFA ratio is $34.98 \%$, by adjusting the secondary air ratio of the first and second layer of burners, analyse the effect of the distribution of oxygen in the main combustion zone on the thermal $\mathrm{NO}_{\mathrm{x}}$ and fuel $\mathrm{NO}_{\mathrm{x}}$. Specific distribution of air and $\mathrm{NO}_{\mathrm{x}}$ output of furnace outlet are shown in Table 2:

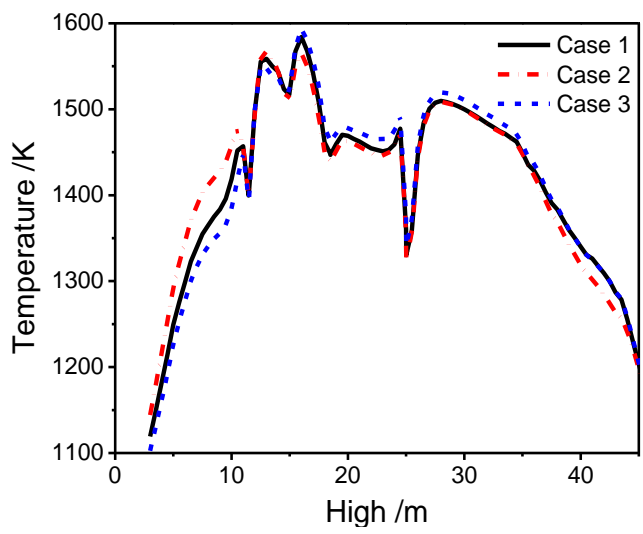

Fig. 14 The section average value of temperature

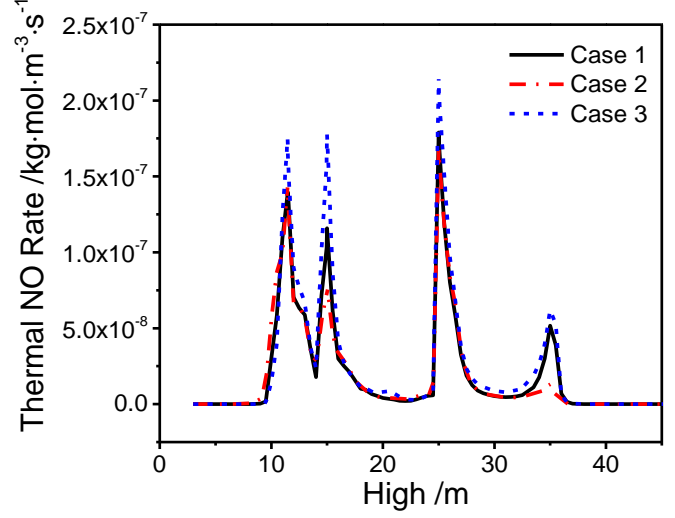

Fig. 15 The section average value of thermal NO rate

Figure 14 is the section average value of temperature with the furnace height under these three conditions. It can be seen from the figure, as compared with the other two conditions, case 3 input more secondary air through the second layer burners, and case 3 has a relatively high temperature in the main combustion zone and burnout zone, so the thermal NO yield is relatively high. It can be seen clearly from the generation rate of thermal $\mathrm{NO}$ in figure 15 , and the thermal NO rate in working condition 3 is relatively larger. But the thermal $\mathrm{NO}$ is relatively small for total NO yield, and the temperature difference between these three conditions is not very large, the thermal NO rate is also in the same order of magnitude, so the three conditions of the heat type NO production is not large. Therefore, there is only a little of difference of thermal NO production among these three kinds of operating. The thermal NO can only be used as reference, and the decisive factor is the fuel NO.

And from the distribution of oxygen in figure 16 can be seen that, under the air staged combustion only near the burner oxygen is more in main combustion zone, so the thermal NO is only generated in the vicinity of the burners. Less oxygen place, heat type NO production is also less, just to verify the previous theory that thermal NO can only be produced at high temperature, and it is affected by oxygen.

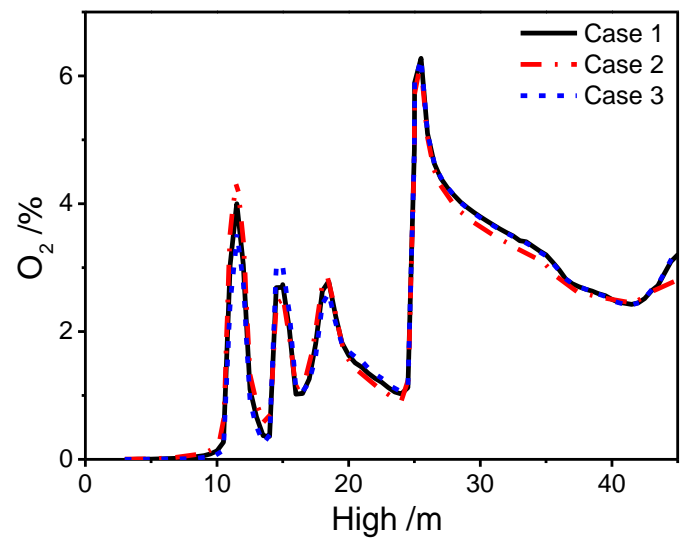

Fig. 16 The section average value of fuel $\mathrm{O}_{2}$

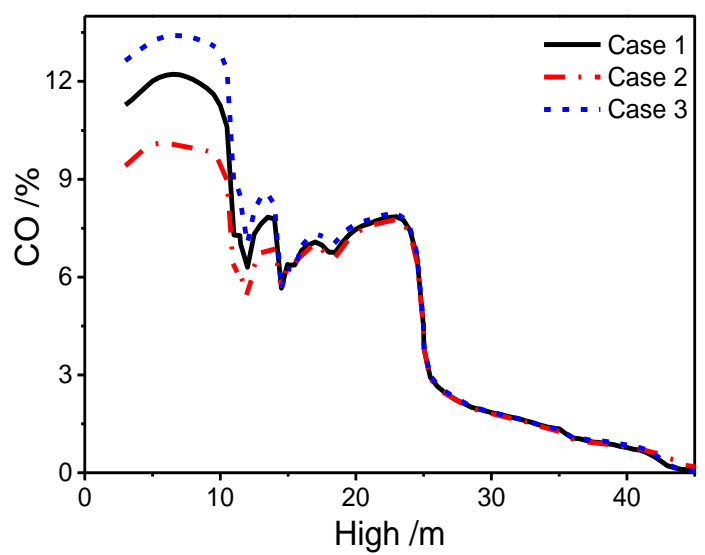

Fig. 17 The section average value of fuel $\mathrm{CO}$

Figure 16 is the section average value of $\mathrm{O}_{2}$ with the furnace height under these three conditions. As can be seen from the distribution of $\mathrm{O}_{2}$, because of case 2 inputting most air in the first layer burners, the oxygen content around the first layer of burners is the highest. And because of case 3 inputting most air in the second layer burners, the oxygen content around the second layer of burners is the highest. From the previous analysis of fuel NO that the formation of fuel $\mathrm{NO}$ is proportional to the amount of oxygen, case 2 around the first layer burners generated more fuel $\mathrm{NO}$, and case 3 around the second layer burners generated more fuel NO, as shown in Figure 18. 
Comprehensive analysis of the fuel type NO formation factors and reduction factors, it is not difficult to get out, case 2 due to the worst reducibility, so that the furnace outlet $\mathrm{NO}_{\mathrm{x}}$ production is relatively more. In order to reduce $\mathrm{NO}_{\mathrm{x}}$ emissions at furnace exit, the distribution of oxygen in the main combustion zone must be reasonable based on the control of the SOFA ratio. The first layer of the air flow cannot be too much, in order to enable the main combustion zone form a good reducibility, reducing the $\mathrm{NO}_{\mathrm{x}}$ production.

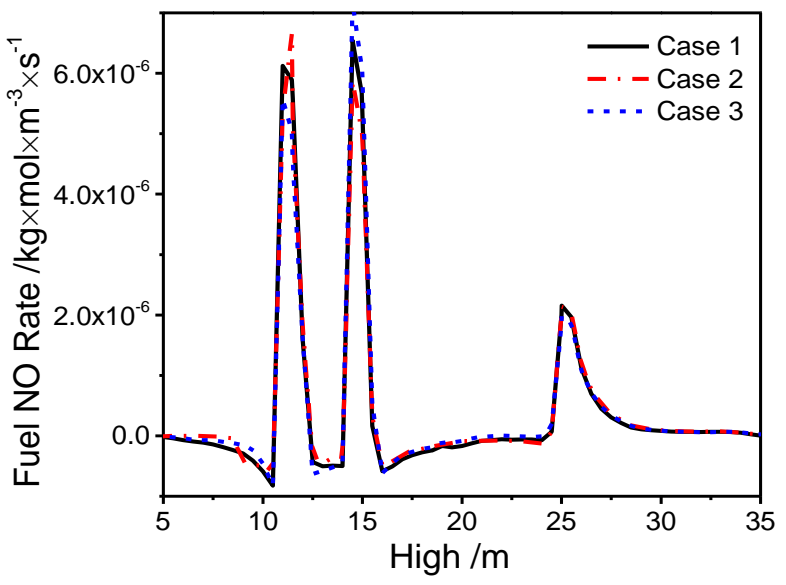

Fig. 18 The section average value of fuel NO rate

\section{CONCLUSIONS}

The formation of thermal NO and fuel type NO emission under the air staged combustion in a tower pulverized coal fired boiler is analyzed. Based on the detailed analysis, the following conclusions can be drawn:

(1) Air staged combustion is beneficial to reduce the $\mathrm{NO}_{\mathrm{x}}$ output of the main combustion zone, so as to reduce the $\mathrm{NO}_{\mathrm{x}}$ emission from the furnace outlet. There is an optimal value of SOFA ratio, and the yield of $\mathrm{NO}_{\mathrm{x}}$ under this condition is the minimum.

(2) Thermal NO can only be produced at high temperature, and it is affected by oxygen. When the oxygen is sufficient under high temperature, thermal NO can be produced in a large amount; when the oxygen is insufficient, even if the temperature is appropriate, there will not be thermal NO formation.

(3) The volatile matter of NO is mainly near the burners in the main combustion zone. If air supply mode of burner is different, the distribution of volatile $\mathrm{NO}$ is also slightly different.

(4) The oxidation of char $\mathrm{N}$ is closely related to oxygen, and is affected by $\mathrm{CO}$. The more oxygen, the more char NO production. When the amount of CO is more, some char NO will be reduced.

(5) A large amount of fuel NO will be generated near the burners in the main combustion zone. But the main combustion zone is in the negative oxygen combustion, a lot of generated NO is reduced. In the burnout zone due to unburned pulverized coal burning again, a large amount of fuel $\mathrm{NO}$ will be produced.

(6) In order to reduce $\mathrm{NO}_{\mathrm{x}}$ emissions at furnace exit, the distribution of oxygen in the main combustion zone must be reasonable based on the control of the SOFA ratio. The first layer of the air flow cannot be too high, in order to enable the main combustion zone form a good reducibility, reducing the $\mathrm{NO}_{\mathrm{x}}$ production.

\section{ACKNOWLEDGEMENTS}

This work was financially supported by National Natural Science Foundation of China (No. 51476103), Public welfare scientific research projects of Shanghai Municipal Bureau of Quality and Technical Supervision (No. 2012-41), Innovation Program of Shanghai Municipal Education Commission (No. 14ZZ134) and Shanghai Pujiang Program (No. 14PJ1407000).

\section{REFERENCES}

Bai, T., Sun, B. M., Kang, Z. Z., Guo, Y. H., Xing, J., 2014, "Numerical Investigation on the Characteristic of Low $\mathrm{NO}_{x}$ Combustion in a 600 MW Tangential Boiler," Boiler Technology, 45(2), 35-40.

http://dx.doi.org/doi:10.3969/j.issn.1672-4763.2014.02.009

Cen, K. F., Yao, Q., Luo, Z. Y., Gao, X., 2004, “Combustion Theory and Pollutant Control," China Machine Press, 410-460.

Cheng, H. Z., Wen, L., Song, Z. C., 2015, "Retrofit on Low-Nox Combustion of a 350 MW Pulverized Coal-fired Boiler and the Parameters Optimization," Journal of Chinese Society of Power Engineering, 35(9), 704-708.

http://dx.doi.org/doi:10.3969/j.issn.1674-7607.2015.09.003

Hill, S. C., Smoot, L. D., 2000, "Modeling of Nitrogen Oxides Formation and Destruction in Combustion Systems," Journal of Bacteriology, 37(5), 873-885.

http://dx.doi.org/doi:10.1016/S0360-1285(00)00011-3

Hong, R. K., Shen, Y. L., Zhao, Z. F., 2012, "Emission Characteristics of CO in a 600 MW and NOx from Opposed Firing Boiler Supercritical Unit," Chinese Journal of Power Engineering, 32(12), 922-927.

http://dx.doi.org/doi:10.3969/j.issn.1674-7607.2012.12.003

Kuang, M, Li, Z. Q., Xu, S. T., Zhu, Q. Y., 2011, "Improving Combustion Characteristics and NOx Emissions Of A Down-fired $350 \mathrm{Mw}$ Utility Boiler with Multiple Injection and Multiple Staging," Environmental Science and Technology, 45(8), 3803-3811. http://dx.doi.org/doi:10.1021/es103598f

Li, D. B., Xu, Q. S., Shen, Y. L., Deng, J. H., Liu, Y. M., Wen, Z. Y., 2014, "Numerical Simulation On Combustion Characteristics in a Tangentially-Fired Boiler with Variable Volumes of SOFA," Journal of Chinese Society of Power Engineering, 34 (12), 921- 931.

Li, Y. H., Wang, S. Q., Zheng, P. A., 2015, "300 MW Lean CoalFired Boiler of Low Nitrogen Combustion Numerical Simulation," Boiler Technology, 46 (03), 5-11.

Ma, L., Fang, Q. Y., Lv, D. Z., Zhang, C., Chen, Y. P., Chen, G., Duan, X. N., Wang, X. H., 2015, "Supporting Information for Reducing $\mathrm{NO}_{\mathrm{x}}$ Emissions for a $600 \mathrm{MW}_{\mathrm{e}}$ Down-Fired PulverizedCoal Utility Boiler by Applying a Novel Combustion System," Environmental Science and Technology, 49(21), 13040-9. http://dx.doi.org/doi:10.1021/acs.est.5b02827

Shen, C. Y., Yang, M., Zhang, Y. W., and Li, Z., 2016, "Effects of Slotted Structures on the Nonlinear Characteristics of Natural Convection in a Cylinder with an Internal Concentric Slotted Annulus," Numerical Heat Transfer, 70(5), 447-459. http://dx.doi.org/doi:10.1080/10407782.2016.1192931

Smoot, L. D., Pratt, D. T., 1979, "Pulverized Coal Combustion and Gasification," Plenum Press, 319-329.

Soete, G. G. D., 1975, "Overall Reaction Rates of $\mathrm{NO}$ and $\mathrm{N}_{2}$ Formation from Fuel Nitrogen," Symposium on Combustion, 15(1), 
1093-1102.

http://dx.doi.org/doi:10.1016/S0082-0784(75)80374-2

Sun, B. M., Wang, D. H., Duan, E. P., Guo, Y. H., Cao, W. H., Zhang, S. H., 2013, "Investigation on $\mathrm{NO}_{\mathrm{x}}$ Formation Characteristics Under Air-Staged Combustion," Chinese Journal of Power Engineering, 33(4), 261-266.

http://dx.doi.org/doi:10.3969/j.issn.1674-7607.2013.04.004

Yang, M., Shen, Y. Y., Xu, H. T., Zhao, M., Shen, S. W., and Huang, K., 2014, "Numerical Investigation of the Nonlinear Flow Characteristics in an Ultra-Supercritical Utility Boiler Furnace," Applied Thermal Engineering, 88, 237-247. http://dx.doi.org/doi:10.1016/j.applthermaleng.2014.09.068

Zhong, Y. L., Zeng, G. F., Li, H. S., Fang, Q. Y., 2015, “Numerical Simulation of the Optimization of the Low-NOx Combustion of a 660 MW Whirling Opposed-Firing Boiler," Chinese Journal of Engineering for Thermal Energy and Power (1), 108-112. http://dx.doi.org/doi:10.16146/j.cnki.rndlgc.2015.01.029

Zhou, H., Mo, G. Y., Si, D. B., Cen, K. F., 2011, "Numerical Simulation of the NOx Emissions in a 1000 MW Tangentially Fired Pulverized-Coal Boiler: Influence of the Multi-group Arrangement of the Separated Over Fire Air," Energy and Fuels, 25(5), 2004-2012. http://dx.doi.org/doi:10.1021/ef200227r 